\title{
A Techno-Functional Interpretation of the Lithic Assemblage from Fontana Ranuccio (Anagni, Central Italy): an Insight into a MIS 11 Human Behaviour
}

\author{
Stefano Grimaldi ${ }^{1,2}$ (D) Fabio Santaniello ${ }^{1,2}$ (D) Diego E. Angelucci ${ }^{2}$ (D) \\ Luciano Bruni $^{1}$ • Fabio Parenti ${ }^{1,3}$ (D)
}

Published online: 28 August 2020

(C) The Author(s) 2020

\begin{abstract}
The techno-functional approach has been employed to better understand one of the more relevant artifact types generally found in Lower Palaeolithic sites: so-called small tools. Particularly, some Italian sites, such as Ficoncella, Isernia and others, have been the subject of specialized studies which provide evidence of an unexpected complexity of technical behaviours mainly related to highly specialized functional properties of the small tools. In this paper, we aim to enhance the debate on the topic by presenting a technofunctional study of the entire lithic assemblage coming from one of the most renown Middle Pleistocene sites in southern Europe, the open-air site of Fontana Ranuccio (Central Italy). Five groups of retouched tools have been identified: cutting tools, where retouch is usually applied to isolate a cutting edge on the blank; pointed tools, where retouch isolates a pointed edge; scrapers; and few other types of retouched tools such as notches and denticulates. We discuss a reconstruction of the reduction sequence in association with the functional features of the produced stone tools in order to better understand these Middle Pleistocene hominin behaviours. Broadly speaking, retouch seems to be used as a real technical process, not distinguishable from the reduction sequence. What seems relevant here is the need to modify the original morphology of flakes and cores in order to shape them into the final objectives of the production. In this perspective, blank production (débitage) and tool shaping (façonnage) are tightly interconnected one on the other.
\end{abstract}

Keywords Fontana Ranuccio $\cdot$ Italy $\cdot$ Middle Pleistocene $\cdot$ Lithic technology $\cdot$ MIS 11

Stefano Grimaldi

stefano.grimaldi@unitn.it

1 Istituto Italiano di Paleontologia Umana, Anagni, Italy

2 Dipartimento di Lettere e Filosofia, Università di Trento, via T.Gar 14, 38122 Trento, Italy

3 Universidade Federal do Paraná, Curitiba, Brazil 


\section{Introduction}

Recent studies have successfully demonstrated a previously unexpected, wide variability in lithic production during the Lower Palaeolithic (among others, Nicoud 2011; Chevrier 2012; Boëda 2013; Aureli et al. 2016). Following the so-called technofunctional approach (hereafter TFA; Lepot 1993; Boëda 1997, 2001; Bonilauri 2010), these studies recognize that in order to better understand hominin behaviour, the techno-functional structure of a tool must be depicted (Bourguignon 1997; Rocca 2013), and we need 'to focus on the very essence of the technical system: reduction sequences, blank management, tool conception, etc.' (Rocca et al. 2016, 404).

Different from the traditional, typologically based approach, the TFA does not take into account either the presence/absence of a single type of stone tool-namely the biface (or handaxe or large cutting tool) — or its techno-morphological features as the exclusive data to compare assemblages. To the contrary, the goal of the TFA is to understand the functional potential of a tool thanks to 'the technical consequences of each removal on the blank (angles, delineation, surface morphology); this analysis leads to the identification of the active edge of the tool (the transformative technofunctional part) as well as the volume of the tool which is presumably held in the hand or eventually hafted during the use. The ultimate purpose of the study is to determine the technical system, expressed in the blank management and in the tool conception' (Rocca 2015, 3).

One of the main achievements provided by the TFA once it was applied to Lower Palaeolithic lithic assemblages is the recognition of a relevant technological and functional complexity shown by the so-called small tools (Burdukiewicz and Ronen 2003 and references therein). As far as the Lower Palaeolithic is concerned, the term 'small tools' refers to the production of small, chipped, generally retouched stone tools found between Europe and southwest Asia (see for instance Rocca 2013; Agam et al. 2015; Alperson-Afil and Goren-Inbar 2016; Villa et al. 2016). Regardless of their chrono-cultural attribution, small tools and bifaces are not necessarily found together in Europe. Following Rocca, Abruzzese, and Aureli et al. (2016) and references therein), small tool production seems to be important in many sites located in central and southern Europe beginning around $1 \mathrm{Ma}$ BP. On the other hand, the association between bifaces, large cutting tools, and small tools becomes more evident starting around $700 \mathrm{ka} \mathrm{BP}$ around the Mediterranean and in Western Europe.

The evolutionary role possibly played by the small tools is still debated. Some authors have suggested a strong adaptive relation between these tools - together with handaxes - and the exploitation of Palaeoloxodon. These authors identify this animal as a key-hunted prey in order to explain cultural development shown by Homo during the Middle Pleistocene (Agam and Barkai 2015, 2018). Unfortunately, use wear analysis proves that these tools were used for a variety of tasks including the processing of Palaeoloxodon carcasses (Lemorini 2018; Aranguren et al. 2019).

Doubts may also be raised (Boëda 2005; Nicoud 2013) against the traditional approach applied to discuss lithic assemblages with or without bifaces. As confirmed by Aureli, Rocca, Lemorini, Modesti, Scaramucci, Milli et al. (Aureli et al. 2016, 181), the 'entanglement between technological and functional objectives seems to be present in Lower Paleolithic contexts (...). These industries raise questions concerning the methodological limits between façonnage and débitage'. Similarly, the limited 
effectiveness shown by the introduction of a classification such as modes 1 and 2 (Clark 1969; see also Carbonell et al. 1999) to characterize Lower Palaeolithic technical systems is clearly demonstrated when lithic assemblages characterized by the presence of small tools are techno-functionally analysed. In fact, small tools show similar technical and use patterns without clear chrono-typological correlations (see for instance Aureli et al. 2016; Rocca et al. 2016).

Up to now, only a few European sites have been studied from a TFA perspective, and only one reduction sequence has been fully modeled, namely for the site of Ficoncella (Italy, Aureli et al. 2016). Nevertheless, our still limited knowledge about the role of small tools can lead to the opening of new frontiers as far as the great complexity and variability of the Lower Palaeolithic technical systems are concerned. In this paper, we aim to enhance the debate on this topic by presenting a techno-functional study of the entire lithic assemblage coming from one of the best known Middle Pleistocene sites in southern Europe, the open-air site of Fontana Ranuccio (Central Italy). The site, dating from MIS 11, has provided abundant faunal remains, bone tools, and human remains; nevertheless, both the stratigraphy and lithic evidence remain poorly defined. Thus, the goal of this paper is to present and discuss this evidence, providing new clues about Middle Pleistocene human behaviour at the site.

\section{Regional Setting}

\section{The Site}

Fontana Ranuccio ( $\left.41^{\circ} 45^{\prime} 38.24^{\prime \prime} \mathrm{N}, 13^{\circ} 6^{\prime} 22.56^{\prime \prime} \mathrm{E}\right)$ is a Middle Pleistocene open-air site located $4 \mathrm{~km}$ north of Anagni (southern Latium, Central Italy), about $50 \mathrm{~km}$ southeast of Rome. More precisely the site is situated near the Fosso delle Mole stream within the Sacco Valley (Fig. 1a). The site is well-known in the literature because of its extraordinary richness of faunal remains, the presence of four human teeth, probably belonging to $H$. heidelbergensis (Ascenzi et al. 1993), abundant lithic and bone tools including the well knownbiface made from an Elephas long bone fragment, and a few highly deteriorated wooden remains. The site has been recently dated to about $407 \mathrm{ka}$ through ${ }^{40} \mathrm{Ar} /{ }^{39} \mathrm{Ar}$ (Pereira et al. 2018), which should correspond to the temperate MIS 11 .

The site was discovered in 1976 during the exploitation of a tuff quarry. At that time, mining activity had already destroyed most of the deposit. Since then, several excavation campaigns were conducted by the team of the Istituto Italiano di Paleontologia Umana, under the direction of A. Segre (1978-2002) and F. Parenti (2004-2018) (Fig. 1b). About $100 \mathrm{~m}^{2}$ of deposit has been excavated, out of an estimated $600 \mathrm{~m}^{2}$ existing (Segre Naldini et al. 2009).

\section{Geology and Stratigraphy}

This section shortly describes the geological context of the Fontana Ranuccio site and its stratigraphy from a geoarchaeological perspective. Data presented here are 

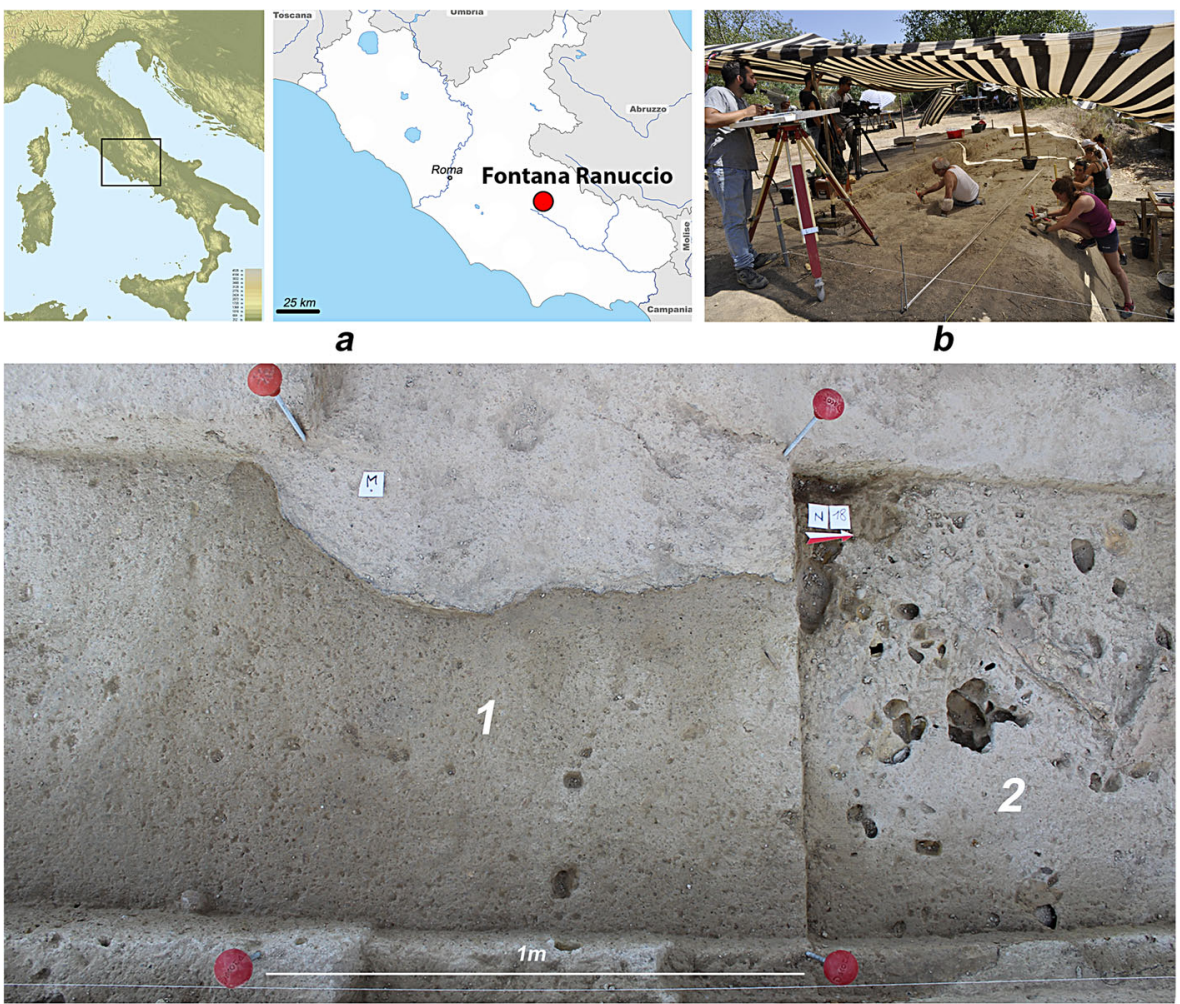

c

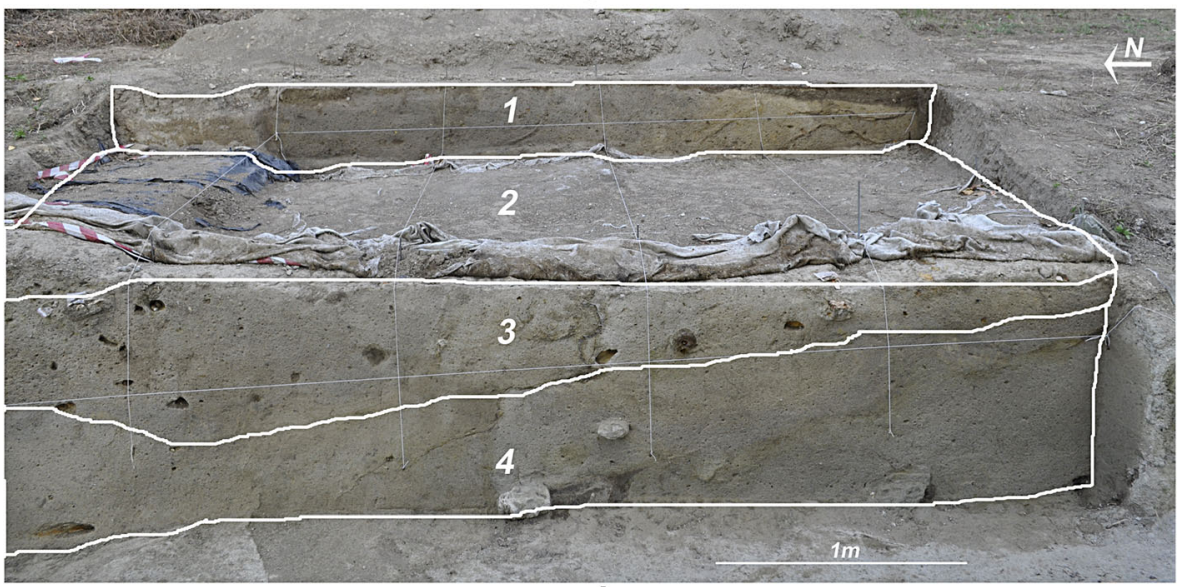

d

Fig. 1 Location (a) of the Fontana Ranuccio open air site (b) and its stratigraphy (c, d) with the archaeological layer (number 2) embedded in volcanoclastic sediments (numbers 1, 3-4)

preliminary and result from fieldwork undertaken at the site during the 2017 and 2018 field campaigns, which also included the collection of undisturbed, intact block soil samples, the analyses of which is still in progress. The site deposit has been classified according to sedimentary, soil, stratigraphic, and archaeological features, in order to 
identify geoarchaeological field units (as defined by Angelucci 2002; GFUs or simply 'units' from now onwards), which are partly derived from the stratigraphic nomenclature proposed by Pereira et al. (2018).

The Fontana Ranuccio site is located in the Anagni basin, which is a part of the tectonically controlled Latina valley, a NE-SW-oriented extensional tectonic depression. Several volcanic complexes, active throughout the Middle and Upper Pleistocene, are scattered around and within the Latina valley (see Pereira et al. 2018 and references therein). The Fontana Ranuccio succession is related to the activity of the Colli Albani volcanic district, located at about $30 \mathrm{~km}$ to the west; the overall lithological and geochemical features of the district are well-known (Marra et al. 2009).

The extant stratigraphic succession corresponds to the top section of the much thicker infilling of the Anagni basin, which is mostly made up of lacustrine and alluvial sediments dating to the Lower and Middle Pleistocene (Muttoni et al. 2009). The geometry and lateral variations of the water-laid sediments and the overlying pyroclastic/volcanoclastic materials at Fontana Ranuccio suggest the occurrence of pre-existing, rather irregular palaeorelief, the actual topography of which is unknown. As a matter of fact, current morphology of the Fontana Ranuccio surroundings bears no relationships with the Pleistocene palaeotopography.

The Fontana Ranuccio succession is made up of pyroclastic and volcanoclastic materials featuring thin intercalations of water-laid sediments. The succession is reported in its full extent by Muttoni et al. (2009); Segre Naldini et al. (2009); and Pereira et al. (2018), while this paper deals with the stratification currently under excavation. The main archaeological layer (layer 2 in Fig. 1c-d) is embedded within complex FR4, a ca. 1.5-m-thick volcanoclastic deposit (it corresponds to the 'Pozzolane nere lahar', see Pereira et al. 2018) (layers 1-4 in Fig. 1c-d). The bulk of this unit is made up of light olive brown (according to Munsell coding), sandy-silt volcanoclastic sediment (the sand fraction contains augite, quartz, leucite, biotite, and occasional feldspars and fragments of volcanic glass), featuring sedimentary structures (such as flat, inclined, cross or convoluted laminations, and intercalations of thin tractive lenses), and hydromorphic diagenetic features (Fe-Mn oxide coatings and intercalations). The palaeosurface is mainly recognized by the presence of artifacts and faunal remains; this surface, which mostly exhibits planar fabric, rests on a poorly developed buried A-BC-C soil profile, which attests to a short phase of surface stabilization during the accumulation of the FR4 deposit. The FR4 complex is derived from the reworking of the underlying FR3 complex (not visible in Fig. 1c-d), a laterally discontinuous primary pyroclastic flow matching the so-called Pozzolane Nere - this is the layer that was dated to $408 \pm 10 \mathrm{ka}$ (Pereira et al. 2018). The underlying FR2 complex (not visible in Fig. 1c-d) includes a set of fine-grained layers - volcanoclastic sandy-silt and compact, dark-coloured, laminated clay layers - as well as an intercalation of ash-fall tephra.

In a nutshell, the archaeological unit at Fontana Ranuccio is a volcanoclastic deposit that mostly derives from the reworking of pyroclastic materials through sedimentary dynamics that can be paralleled to alluvial-like processes. The accumulation of the unit was interrupted by a short hiatus that gave rise to the weak soil profile below the palaeosurface (and to related evidence of subaerial conditions and surface stabilization, such as the distribution and orientation patterns of archaeological remains and the weak bioturbation), the delineation of which corresponds to an almost flat, slightly irregular, surface. 


\section{Archaeological Evidence}

Palaeontological remains from Fontana Ranuccio have been widely studied (Strani et al. 2018 and references therein). Among the large mammals, fifteen taxa have been identified, with Artiodactyla - mainly Cervids and Bovids - being the best-represented order (68\% of faunal remains). Palaeoloxodon antiquus, Hippopotamus amphibius, Ursus deningeri, Crocuta crocuta, and Macaca sylvanus are also present, while carnivore remains are rather uncommon. Following several scholars (see Strani et al. 2018 and references therein), the large mammal assemblage of Fontana Ranuccio represents the last faunal unit of the Galerian Mammal Age that occurred in the Middle Pleistocene at approximately $0.45-0.40$ Ma. It was replaced by the Aurelian Mammal Age, around $0.35 \mathrm{Ma}$ by new taxa dispersed in the Italian peninsula such as Canis lupus, Ursus spelaeus, the 'steppe horse' Equus hydruntinus, new large and medium-sized deer (Megaloceros giganteus, Dama dama tiberina), and the water buffalo Bubalus murrensis. Palaeoenvironmental reconstructions mainly based on dietary adaptations of the ungulate community and small mammal taxa suggest a region characterized by grasslands inhabited mostly by groups of large bovids (B. primigenius) and grazing perissodactyls (Stephanorhinus sp., Equus cf. E. mosbachensis). The large number of cervids seems also to attest the presence of wooded environments. It is worth noting that different local environmental conditions might have been present along the Italian peninsula with the spread of woodlands on the Tyrrhenian side of Central Italy, such as witnessed in Fontana Ranuccio.

Most of the human remains referable to the Middle Pleistocene from the Italian Peninsula have been found in Central Italy (Manzi et al. 2011). Four human teeth were unearthed at Fontana Ranuccio (Cassoli and Segre Naldini 1984; Segre and Ascenzi 1984; Ascenzi et al. 1993). Recently, some attempts have been made to define their phylogenetic features: while some authors suggest that the remains certainly fall within the complex mosaic constituted by the fossil hominins of the European Middle Pleistocene (Rubini et al. 2014), other authors support a scenario in which, even if the overall Neanderthal morphological dental template was preconfigured at least 450 to $430 \mathrm{ka}$, other human groups, not necessarily related to the Neanderthal lineage, may have existed in Eurasia around the same period (Zanolli et al. 2018).

Despite the importance of the site, lithic and bone tools have been only reported (Segre Naldini et al. 2009 and references therein) without a clear technological and functional description. The lithic assemblage is the topic of this paper and will be discussed below. The study of the bone assemblage is still ongoing.

\section{Material and Methods}

The lithic assemblage from Fontana Ranuccio is made up of 802 stone tools and was entirely analysed. It is currently stored at the Italian Institute of Human Paleontology in Anagni. In this paper, we have not included the four bifaces found out of stratigraphic context, which were already described elsewhere from a morphological point of view 
(Biddittu and Segre 1984; Biddittu and Bruni 1987). More than 50\% of the implements were found during the excavations. The remaining artifacts were found in the sediment of the palaeosurface, locally removed during the quarry activity. Several details allow us to analyse the entire collection as a whole and to discard the hypothesis that the retouched tools could be the by-products of post-depositional mechanical damage. First, lithics are only found in the palaeosurface previously described-layer 2, compare Fig. 1-in tight connection with bones of large mammals as well as with bone tools. As stated above, the stratigraphic context related to the palaeosurface formation process clearly supports its stable exposure for a short time span during which animals and humans interacted. Animal bones and teeth show a very good state of preservation allowing detailed analysis on the fauna dietary adaptation (Strani et al. 2018). Similarly, very rare mechanical alterations have been found on stone implements while the general morphology of the tools is very well-preserved, and all the lithics show almost identical features (see below).

A preliminary functional analysis on a sample of stone retouched tools strongly supports the overall homogeneity of the assemblage (Marinelli et al. 2019). In fact, despite widespread alteration of the lithic surface — namely, glossy appearance — at high magnifications under the metallographic microscope, macro-traces of use, occurring as edge-removals and macro-edge rounding, have been observed on implements coming from the palaeosurface. This was possible because the edges, retouched or not, did not suffering mechanical damage (Marinelli et al. 2019, 62), and they show a very well preserved morphology (Marinelli et al. 2019, 63).

Raw material is represented by small pebbles (no more than 5-7 cm of length) of chert or finely grained quartzite. Pebbles could have been collected along the banks of Sacco valley (about 3-5 km far from the site) as well as in several tributaries of the Sacco river. As consequence, their geological origins should be found in the chertbearing formations located in the Apennines of Central Italy, but it is not possible to be more precise at this regard. By considering that raw materials were probably collected as small pebbles from riverbanks, our interest was not to differentiate precisely the raw material provenance but to highlight variability among knappable raw materials showing different petrographic properties. For this reason, we decided to divide the lithic assemblage into three main raw material categories: non-aphanitic chert (almost half of the assemblage), aphanitic chert (almost a third of the assemblage), and other

Table 1 The Fontana Ranuccio lithic industry: distribution of raw material types according to technological blank groups

\begin{tabular}{lcccccc}
\hline & Non-aphanitic flint & Aphanitic flint & Other raw materials & Indet. & Total & $\%$ \\
\hline Cores & 76 & 34 & 15 & 0 & 125 & 15.6 \\
Flakes & 225 & 135 & 79 & 7 & 446 & 55.6 \\
Fragments & 87 & 54 & 37 & 2 & 180 & 22.4 \\
Indet. & 1 & 2 & 6 & 20 & 29 & 3.6 \\
Not worked & 5 & 2 & 14 & 1 & 22 & 2.7 \\
Total & 394 & 227 & 152 & 30 & 802 & \\
$\%$ & 49.1 & 28.3 & 19.0 & 3.7 & & \\
\hline
\end{tabular}


heterogeneous types of chert from small pebbles (Table 1). The aim of this distinction was to stress possible differences in terms of reduction sequences when raw materials with different knappable qualities are concerned. Not surprisingly, no real technological or morphological differences can be reported as far as these raw material groups are compared.

Our main goal is twofold: the reconstruction of the reduction sequence-which is achieved by means of a technological approach - and the identification of the ultimate objectives searched for by the prehistoric human group - which is achieved by means of a TFA. The TFA - integrating the potential of several already known methodologies such as technology, typology, morpho-metric analysis, macro-wear analysis, and experimentation-allows a better understanding of the tools by the recognition of their functionally different parts and how these parts have been technologically designed. This means that it is possible to define which is the active edge and where the active edge of the tool is; it is also possible to identify the passive contact surface between the tool and the gripper such as the hand or an handle, i.e. the surface which is subjected to prehension forces (hereafter called prehension part of the tool). The active and the prehension parts on a tool are defined as 'a set of elements and/or technical characters coexisting in a synergy of effects' (Boëda 1997, 34). Each is a 'technically coherent part of a tool that plays a role in its utilization: for example, the cutting-edge and the handle of a modern knife. These two parts have particular morphological and technical characteristics, both necessary for the tool operation' (Aureli et al. 2016, 173).

On this basis, we carried out quantitative and qualitative analyses of the lithic assemblage, by analysing the technological, typological, and morphological features of the tools, in association with an extensive experimental activity and a macro-use wear analysis. Accordingly, the following quantitative data have been recorded: (a) dimensions (length, width, thickness) of the cores, flakes, and retouched fragments (as described in Inizian et al. 1999); (b) angles of retouched and unretouched edges (as described in Andrefsky 2005); at this regard, according to the dimensional pattern of the Fontana Ranuccio tools, we defined two main ranges of value, i.e. steep and flat retouched edges, where the limit among them is about $40-45^{\circ}$. We also recorded the following qualitative data: (a) type of blank (cores, flakes, and retouched fragments); (b) type of butt (following Inizian et al. 1999); (c) presence and localization of the cortex; (d) diachronic sequence of scars on the upper surface of the flakes and on the cores (following Boeda 1994); (e) presence/absence of anvil percussion on the basis of the recognition of diagnostic marks (following Bietti et al. 2009); (e) nature, location, and extension of fractures, 'debordant' side/s, retouched edges; (f) retouch characteristics (following Inizian et al. 1999); (g) typological definition (following Bordes 1961); (h) presence and characterization of macrotraces (following Marreiros et al. 2015 and references therein). Macro-traces have been analysed by the aid of a Leica MZ12.5 optical microscope ranging from $\times 8$ to $\times 100$ magnifications. The criteria used to reconstruct the reduction sequence follow the well-known technological approach as was suggested by E. Boeda (1994), while the integrated approach of quantitative and qualitative data was useful to define the technofunctional features of the Fontana Ranuccio lithic implements (compare Fig. 8). 


\section{Results}

\section{An Overview of the Assemblage}

In Table 1 , the frequencies of each technological category are shown. Flakes $(N=446$, about $56 \%$ ) comprise more than a half of the assemblage, while cores are much less represented $(N=125$, about $16 \%)$. The remaining implements include 180 fragments, 29 indeterminable pieces, and 22 unworked pieces. Most of the assemblage was knapped by means of direct percussion with hard hammers. Anvil percussion is also attested to, reaching $17 \%$ of the implements (Fig. 2). The frequency of anvil percussion must be considered as an underestimate of the real importance of this technique in a lithic industry. In fact, various features, such as retouch activity or the small dimensions of the implements, do not allow the preservation of anvil marks on the tools, so it is hard to provide an accurate estimate for anvil percussion in the Fontana Ranuccio assemblage. Nevertheless, on the basis of a long-term experience on this subject (Bietti and Grimaldi 1991; Grimaldi 1996; Grimaldi et al. 1999; Grimaldi and Santaniello 2014; Song et al. 2019), also supported by a robust experimental dataset (Bietti et al. 2009), we suggest anvil percussion could have played a very important role during the Middle Pleistocene in the production of blanks made from small pebbles or cobbles such as the case in Fontana Ranuccio as well as in other European sites (see for instance Mourre and Jarry 2009-2010 and references therein).

The most remarkable feature of the Fontana Ranuccio lithic assemblage is the degree of retouch. Retouch is observed on most of the cores $(N=84,67 \%)$ as well as on flakes $(N=263,59 \%)$, and it affects $43 \%$ of the assemblage (including three retouched fragments). Tool retouch does not show any evidence clearly associated to anvil percussion. In fact, as described below, retouched tools show few, very wellstandardized morphologies obtained by means of intense retouch having as the main goal to shape the original raw morphology of the knapped blanks. That is why the use of the anvil technique for retouch activity-different from what is elsewhere observed in Italy (see for instance the site of Isernia La Pineta in Crovetto et al. 1994) where it produced unstandardized retouched types - should be here discarded.

In terms of size, retouched cores are smaller in all dimensions when compared with unretouched cores. To the contrary, retouched flakes are larger in all dimensions when compared with unretouched flakes (see Table 2). Quite interestingly, retouched cores and flakes show a very similar length and a small difference in width. Retouched cores are thicker. We argue here that the dimensional choice - the length, in particularcould be considered as a technical feature of retouched implements. Even if length could be partially connected to the size of the available pebbles, our data show a very high level of standardization after the retouch. For us, this evidence cannot be considered just a consequence of raw material constraints.

Retouch shows very high morphological variability. It is characterized by flat (lower than $30^{\circ}$ ) or steep (higher than $30^{\circ}$ ) retouch, denticulated edges, and notches. Retouch may be invasive or marginal, and located all around the perimeter of the tool or just at a few spots. Five groups of retouched tools have been identified (Table 3). Unmodified cutting tools and flat-retouched cutting tools represent two types of the same group of implements — named cutting tools (Fig. 3a-f) — which are functionally related to cutting activities. Steep retouch is mainly used to shape the tool in order to isolate an 

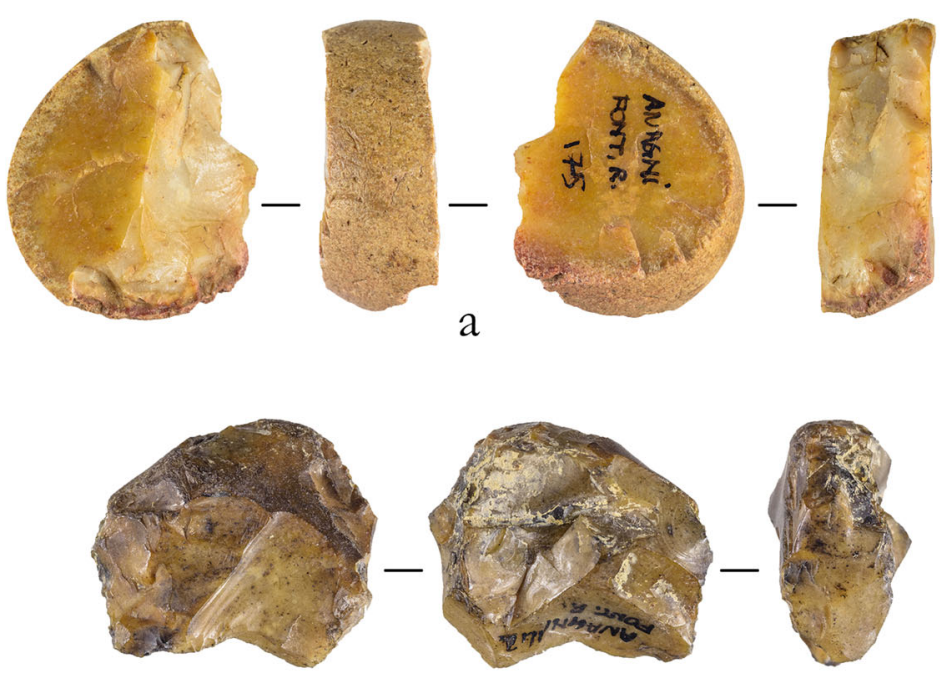

$\mathrm{b}$

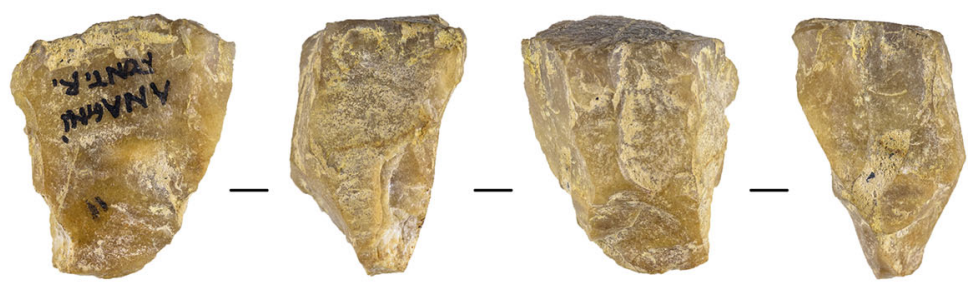

C

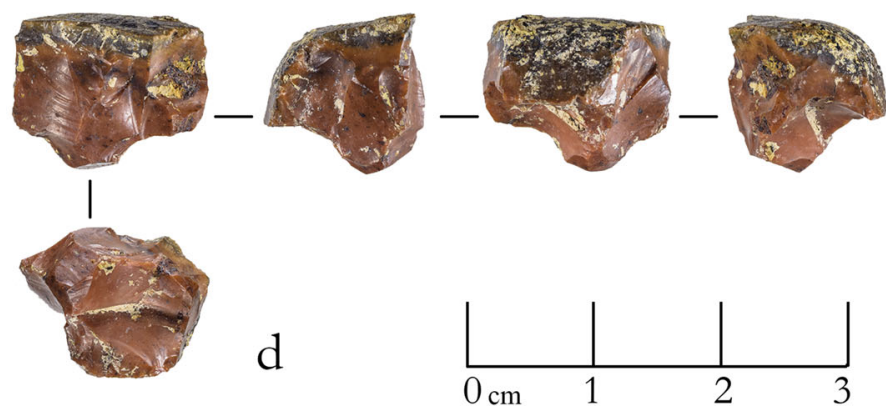

Fig. 2 The Fontana Ranuccio lithic industry. Cores knapped by means of anvil percussion (Credits: P. Chisté, University of Trento)

unmodified cutting edge (Fig. $4 \mathrm{c}-\mathrm{f}$ ) but a flat, invasive retouch is also used to shape the cutting edge (Fig. 4g). The two types represent more than $66 \%$ of the retouched flakes. Unmodified cutting tools (about $52 \%$ of the retouched flakes) are much more abundant than flat-retouched ones (15\% of the retouched flakes). Cores are observed only as unmodified cutting tools (41\% of the retouched cores). A second group is represented by the pointed tools (Fig. $3 \mathrm{~g}-\mathrm{j}$ ): these are cores $(39 \%$ of the retouched cores) and flakes (about 12\% of the retouched flakes) where retouch is used to shape 
Table 2 The Fontana Ranuccio lithic industry: average dimensions with standard deviation of the retouched and non-retouched flakes/cores

\begin{tabular}{|c|c|c|c|c|c|c|c|c|c|c|c|c|}
\hline \multicolumn{7}{|c|}{ Retouched } & \multicolumn{6}{|c|}{ Non-retouched } \\
\hline & Length & STD & Width & $S T D$ & Thickness & $S T D$ & Length & $S T D$ & Width & STD & Thickness & STD \\
\hline Cores & 16.5 & 5.9 & 18.0 & 7.0 & 12.1 & 6.4 & 19.4 & 10.4 & 20.4 & 9.4 & 15.0 & 9.0 \\
\hline Flakes & 16.4 & 7.0 & 15.0 & 6.4 & 5.6 & 3.2 & 13.0 & 5.6 & 11.4 & 5.0 & 3.7 & 2.6 \\
\hline
\end{tabular}

the overall morphology of the implement in order to isolate a pointed edge (Fig. 4a-b). These two groups - cutting and pointed tools - are the most representative among the Fontana Ranuccio assemblage, and they are here considered as being the main functional aim of the retouch.

The other two groups of retouched tools are represented by scrapers with marginally retouched edges and by scrapers with steep and intensive retouch. They are interpreted as different types of scraping tools, and they account for less than $20 \%$ of the retouched assemblage. The last group is represented by notches and denticulates and includes six implements.

\section{Techno-Functional Analysis}

Following our perspective, we need to better define the production dynamics of the blanks and their functional aims. Accordingly, a reduction sequence should be considered as an adaptive response by a human group to local environmental conditions. Thus, a lithic industry has to be analysed as a totality of technical choices and economic purposes that satisfy the needs of that human group living at that site at a given time. Then, we must go further towards the reconstruction of the core of hominin life: we must interpret it from an adaptive perspective. This can be done by the identification of what we call the 'technical objectives' pursued by prehistoric humans. The identification of the technical objectives, which justify the reduction sequence, must be assured by other kinds of data, such as those from use wear, raw material provenance, and technology analyses. Without this identification, any reconstructed reduction sequence remains an empirical description used to better visualize collected data.

Table 3 The Fontana Ranuccio lithic industry: frequencies distribution of the retouched blanks according to their typological morphology

\begin{tabular}{lrrrrrrrr}
\hline & \multicolumn{1}{c}{ Cores } & \multicolumn{1}{c}{$\%$} & \multicolumn{1}{c}{ Flakes } & $\%$ & Fragments & $\%$ & Total & $\%$ \\
\hline Cutting tools & 35 & 41.7 & 136 & 51.7 & 3 & 100 & 174 & 49.7 \\
Flat-retouched cutting tools & 0 & 0.0 & 40 & 15.2 & & & 40 & 11.4 \\
Pointed tools & 33 & 39.3 & 31 & 11.8 & & & 64 & 18.3 \\
Marginal retouched scrapers & 10 & 11.9 & 33 & 12.5 & & 43 & 12.3 \\
Heavy retouched scrapers & 3 & 3.6 & 20 & 7.6 & & 23 & 6.6 \\
Other tools & 3 & 3.6 & 3 & 1.1 & & 6 & 1.7 \\
Total & 84 & & 263 & & 3 & & 350 & \\
\hline
\end{tabular}



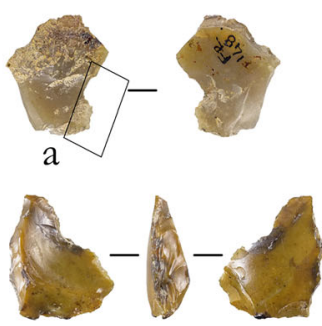

d
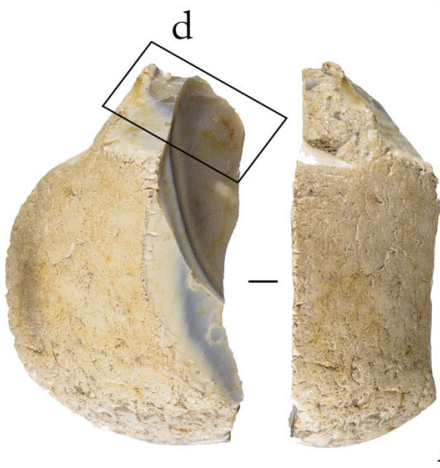

f
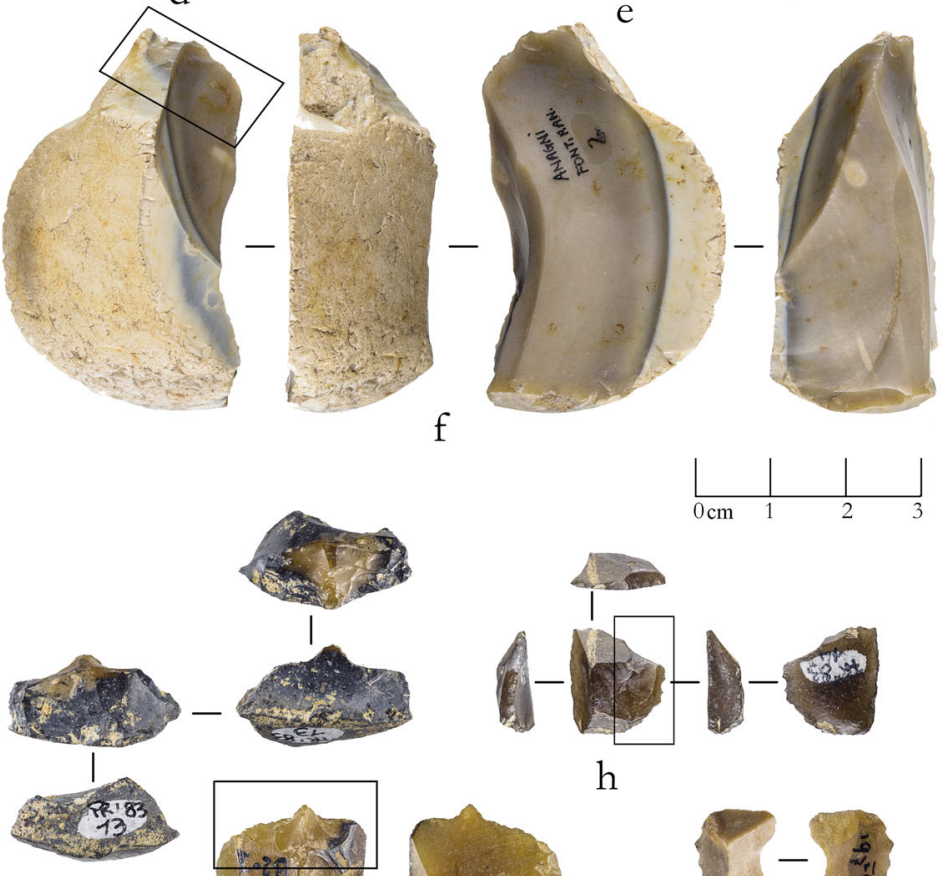

g
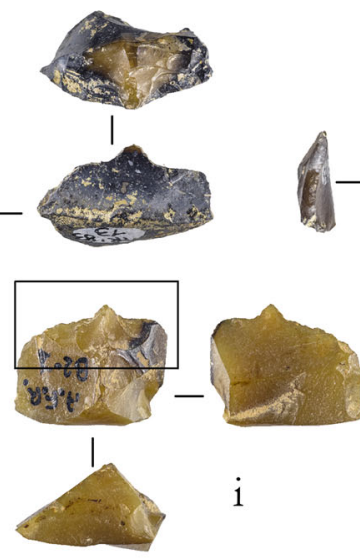

i

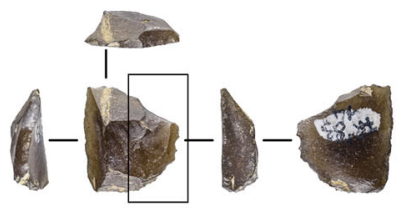

$\mathrm{h}$

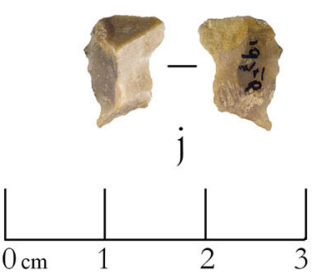

Fig. 3 The Fontana Ranuccio lithic industry. The two main techno-functional aims of the lithic production: cutting tools $(\mathrm{a}-\mathrm{f})$ and pointed tools $(\mathrm{g}-\mathrm{j})$. Black rectangles highlight the transformative part of the tools shown in Fig. 4 (Credits: P. Chisté, University of Trento)

\section{The Reduction Sequence}

Both direct percussion by means of hard hammer and anvil percussion are used in any stage of the reduction sequence in order to knap the raw material and to produce blanks suitable for retouch. The choice whether to use direct percussion or anvil percussion could relate to the original morphology of the raw material-for instance, rounded pebbles are easier to knap by means of anvil percussion - but anvil marks are also observed on blanks clearly produced from blocks or other, not rounded pebbles. Thus, 

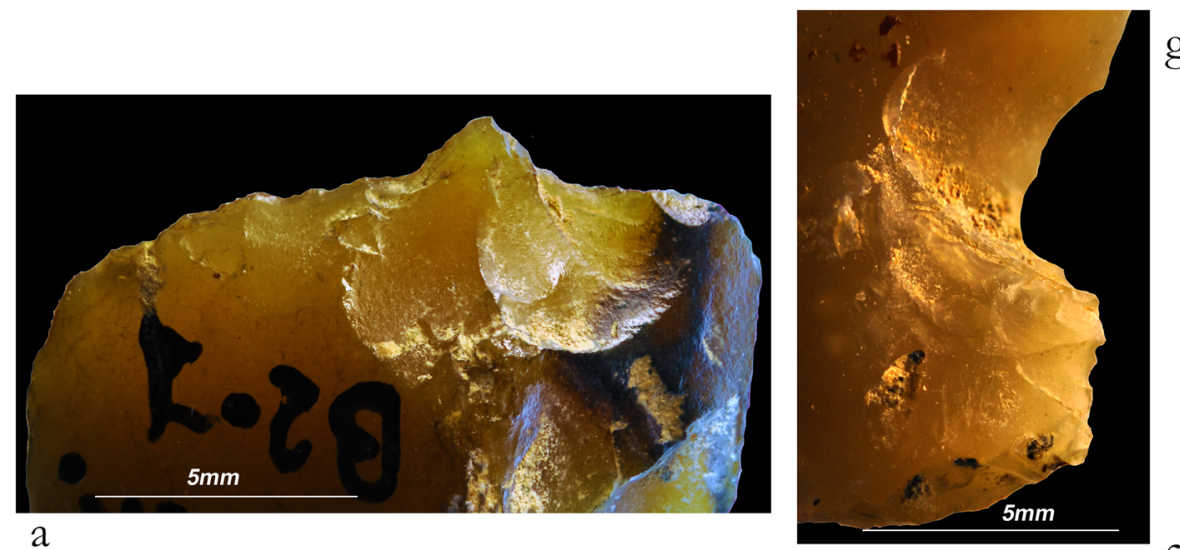

a
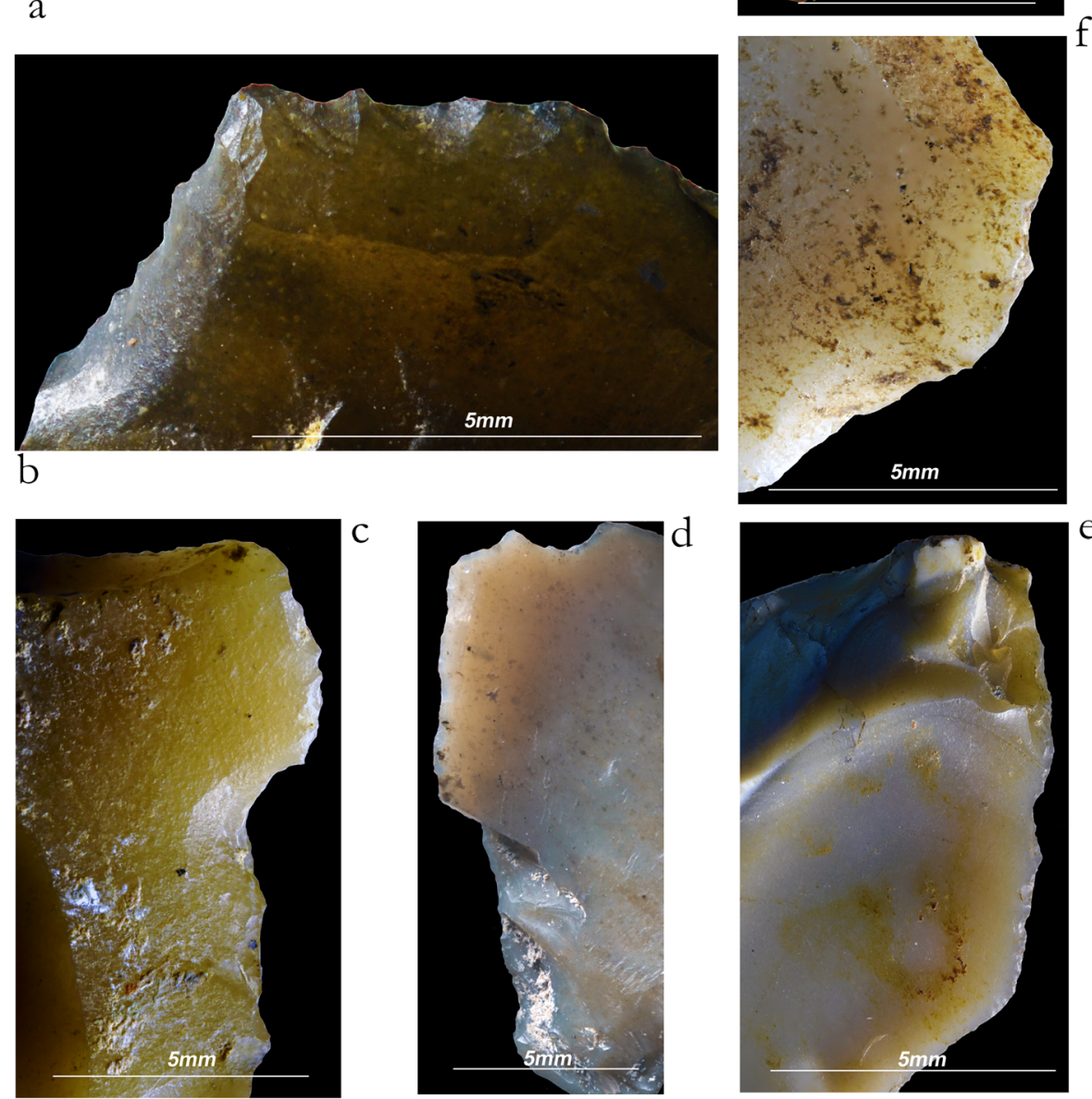

Fig. 4 The Fontana Ranuccio lithic industry. Details of the transformative part of the tools shown with black rectangles in Fig. 3: Pointed tools (a, b) and cutting tools (c, d) (Credits: S. Grimaldi, University of Trento)

it remains difficult to establish a behavioural model to explain how the human group chose when to apply one technique or the other. 
Three main stages have been identified (Fig. 5): initialization, production, and manufacturing. During the first stage, a knapping strategy is selected based on the raw materials natural morphology: raw material can be knapped mainly by means of direct percussion in order to produce (i) cortical flakes from one or from both surfaces of the core, or (ii) a cortical flake may be struck off from a pebble in order to set up a core with a transversal, flat striking platform suitable for elongated, unidirectional blanks, or (iii) a pebble/block may be split into two parts mainly by means of anvil percussion (Fig. 2). Once again it is worth stressing that direct percussion and anvil percussion may be substituted for one another in any of these choices thereby producing a large variety of blanks and fragments despite the limited number of knapping strategies. For instance, anvil percussion also may be used to 'slice' pebbles in order to produce fragmented blanks suitable for being used, with or without retouch. Regardless of the selected percussion technique as well as the selected knapping strategy, any product from the initialization stage could be exploited by means of a different percussion technique in order to produce one of the possible choices described above. For instance, a half pebble produced by means of anvil percussion could be used as a core with a flat striking platform in order to produce elongated flakes by means of direct percussion, or it could still be sliced by means of anvil percussion, or it could be retouched.

The next stage, production, is tightly interconnected with the previous one, initialization. The production stage here remains quite indefinable from a mere technical perspective (Figs. 6 and 7); a speculative argumentation we wish to suggest here refers to a possible lack of a real cognitive process in terms of planning of the production process. In other words, we think that at this stage of the reduction sequence, the Fontana Ranuccio hominins do not need to foresee the final products of their knapping activity. Their goal seems to be the production of as many blanks as possible while looking for some morphological and dimensional features suitable for being retouched during the third and final manufacturing stage of the reduction sequence. This evidence should not be seen as opposite to what has been already suggested by other authors in the same region; in fact, we think we are probably dealing with a different behaviour developed in peculiar environmental conditions such as given by a 'butchery (scavanging) site' - like Fontana Ranuccio presumably has to be considered-by more or less the same hominins who 'had a clear understanding of the specific qualities of flint which came in the form of rather small pebbles and was deemed desirable for the making of small tools' (Villa et al. 2016, 24).

The manufacturing stage sees the selection of those blanks that ensure the features described above. The selected blanks - cores, flakes, half-pebbles, fragments - are retouched in order to be shaped into the desired objectives. It is mainly during this stage that a sort of predetermination appears, a process performed by means of retouch and characterized by a clear vision in the hominin's mind of what the blanks must become and how they must be used.

\section{The Functional Aim}

As stated above, the functional aim of the Fontana Ranuccio lithic assemblage is argued to be the production of blanks - flakes, cores, and also fragments - which are heavily shaped by retouch in order to produce dimensionally as well as morphologically 


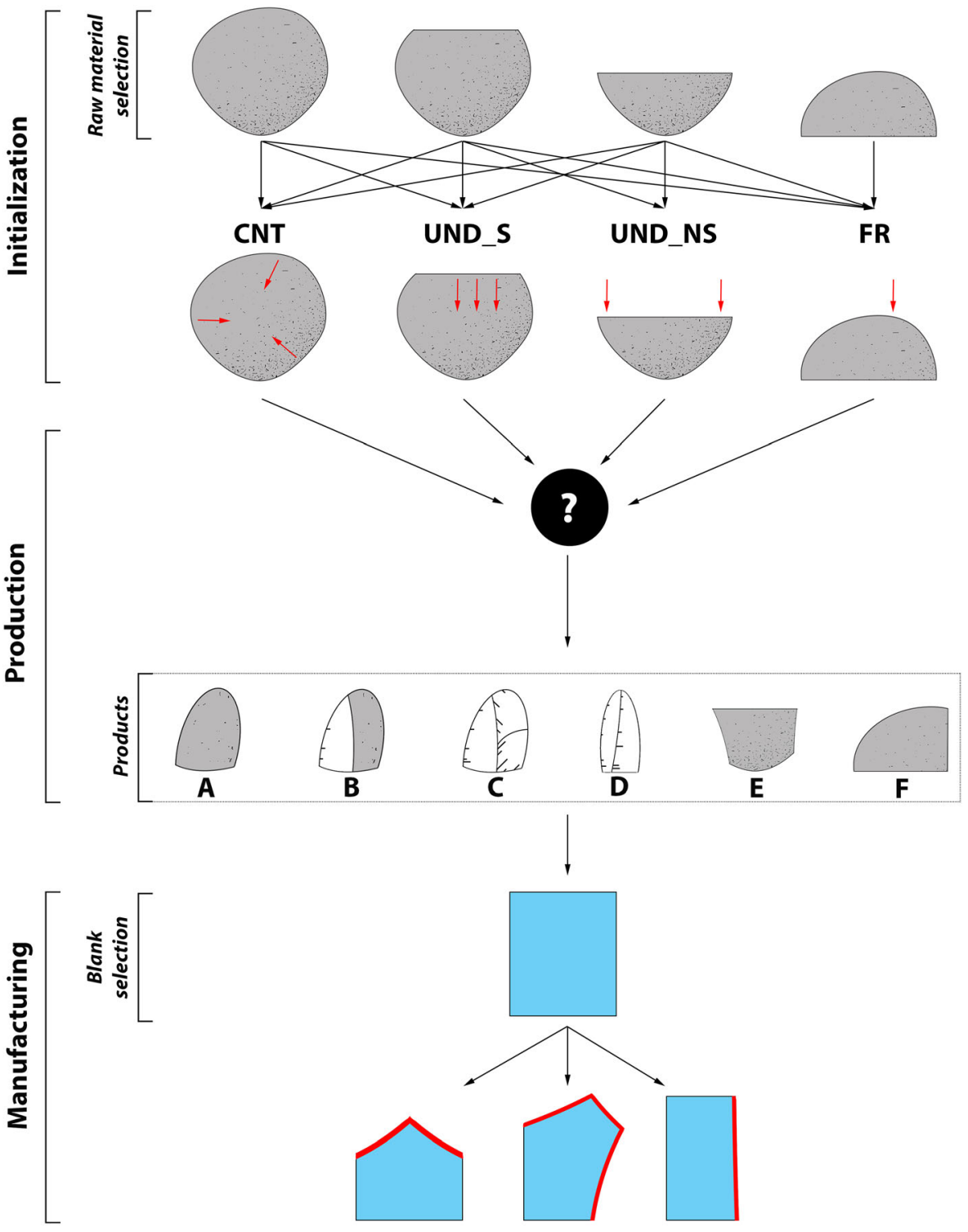

Fig. 5 The Fontana Ranuccio lithic reduction scheme. Initialization: direct or anvil percussion may be used to exploit raw material according to its original morphology. Cores may be knapped or split for a centripetal (CNT) or a sequencial (UND-S)/not-sequencial (UNS-NS) unidirectional production; pebbles may also be split to be directly shaped into tools or knapped as a core (FR). Production: cores, flakes, and fragments are exploited by means of direct and/or anvil percussion to produce suitable blanks such as cortical (A), semicortical (B), centripetal (C), or elongated (D) flakes or cores (E) or fragmented/split pebbles (F). Refinement: selected blanks are retouched to produce the desired objectives such as pointed, cutting, or scraping tools

standardized retouched tools, namely cutting and pointed tools. Regardless of the retouched morphology, we need to distinguish retouch that is systematically applied to shape the prehension part of the tools from the retouch sporadically applied to shape the transformative part of the tool. Cutting tools may be easily identified because 




a
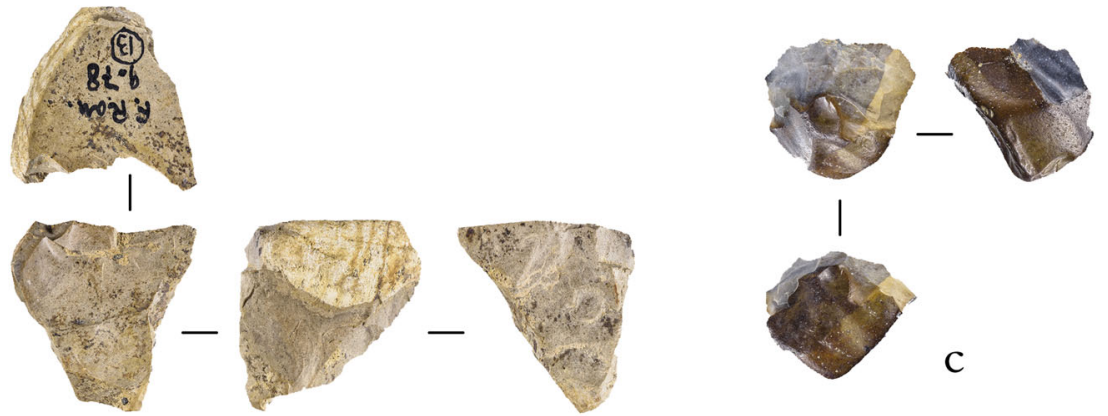

$\mathrm{b}$
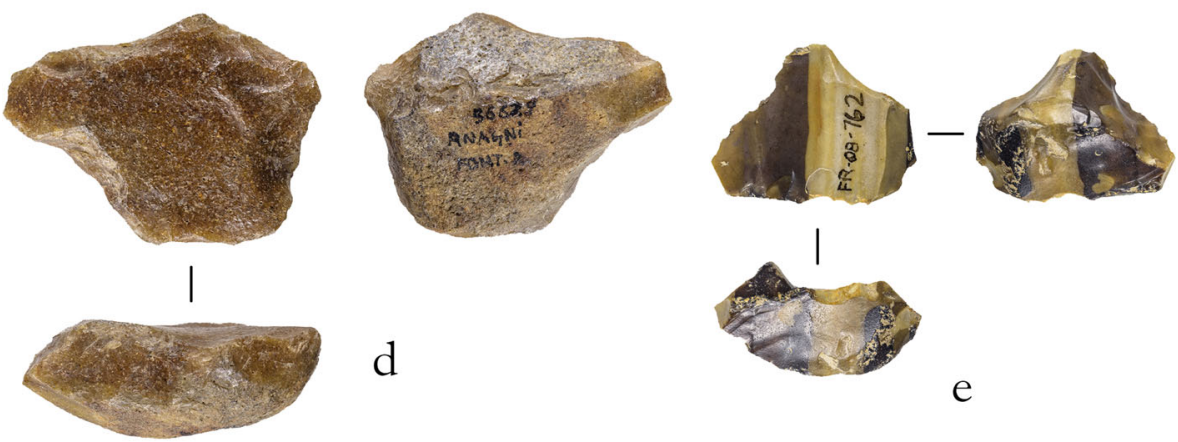

d

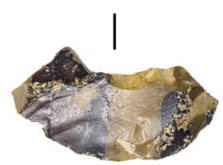

e
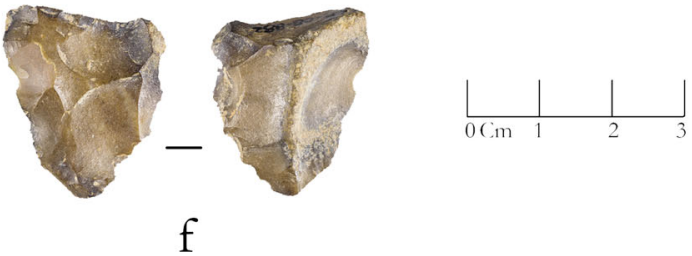

f

Fig. 6 The Fontana Ranuccio lithic industry: the cores. (a) 'chopping-tool'-like, double surface knapped core; (b, c) unidirectional production for elongated flakes; (d, e) 'Levallois'-like cores; (f) centripetal production (Credits: P. Chisté, University of Trento)

retouch is usually applied to isolate a cutting edge. Retouch shapes the prehension part of the tool while the transformative part is represented by a portion of the original cutting edge of the blank. It is worth mentioning that a very flat and invasive retouch could also be applied to shape or, probably, to rejuvenate the original cutting edge. 


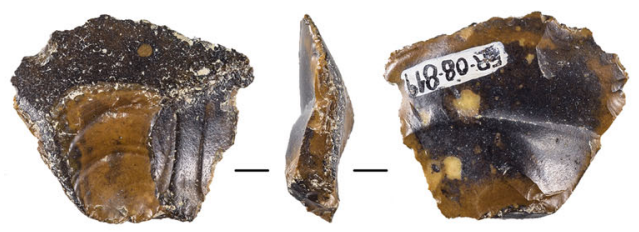

a
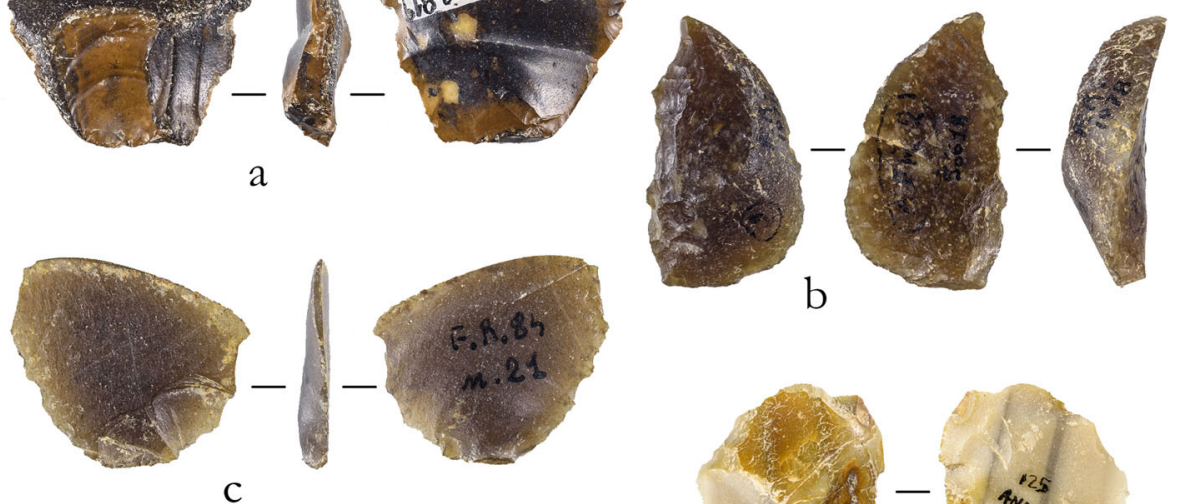

$\mathrm{b}$
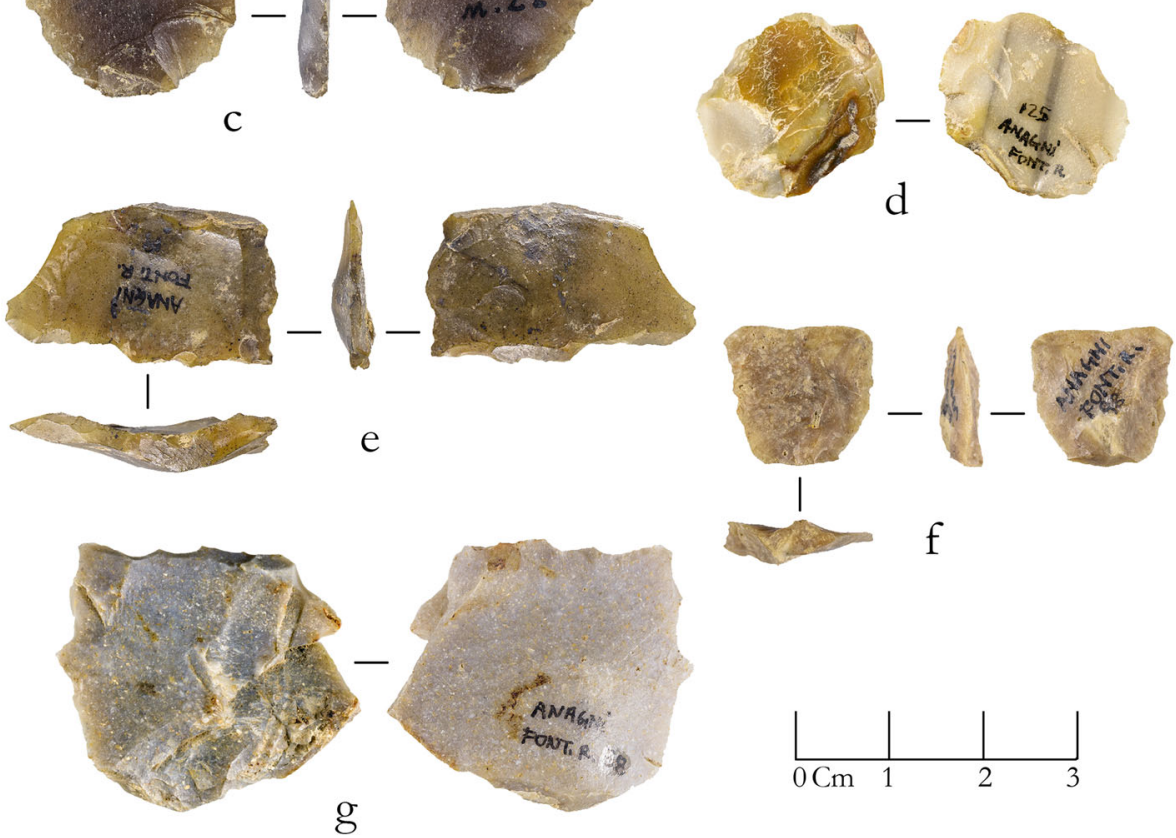

Fig. 7 The Fontana Ranuccio lithic industry: the flakes. (a-d) cortical flakes (flake 'c' from a core-flake); (e, f) flakes showing unidirectional scars; (g) flake showing centripetal scars (Credits: P. Chisté, University of Trento)

At least three variants are observed in how retouch may be applied to isolate the transformative part of the tools: (a) the cutting edge is isolated by means of a retouched edge on one side and a notch on the other side (Fig. 8n-p); (b) the cutting edge is isolated by means of two notches or two retouched edges (Fig. 8q-s); (c) the cutting edge is isolated by means of a single notch, sometimes in association with a fracture or a natural steep side of the blank (Fig. 8m, t-u). Quite interestingly, the transformative part (cutting edge) of these tools shows very limited dimensions, frequently reaching only a few millimeters in length. Regardless of its dimensions, what seems to be functionally important here is a straight or convex or, more rarely, angulated cutting edge. The prehension part of the tool does not show truly standardized features as far as the retouch morphology is concerned. In fact, it can be shaped by a large variety of technical options - such as flat or steep retouch, and notches - or it can also include the 
natural morphology of the blank - such as débordant and/or cortical sides - as well as fractures. Regardless of the technical choice, the aim in shaping the transformative part of the tool seems to be the production of steep sides.

Pointed tools show the same technical choices described above to shape the prehension part of the tool, but here the aim is to isolate a pointed edge as the transformative part of the tool. In this case, the pointed edge is made by means of two retouched notches (Fig. 8a-c) or by means of a steep retouch on one side and a notch (Fig. 8d-f) - or sometimes another retouch (Fig. 8g-1) —on the other side. Interestingly, when a pointed edge is produced, notches show a concave profile and a marginal and/or flat retouch is often superimposed; the functional meaning in doing this could be tentatively related to the creation of thinner edges on both sides of the pointed edge so as to provide a better functional attitude.

From a functional perspective, cutting and pointed tools may be interpreted as multipurpose tools useful to cut, to engrave, to shave, etc., different materials; preliminary macro-use wears provide some clues at this regard, indirectly confirming the use of the active edges technically determined, but a more developed interpretation is difficult to be reach. A functional analysis is still currently ongoing.

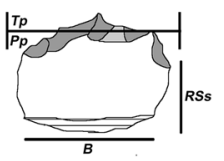

a

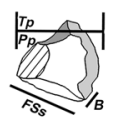

f

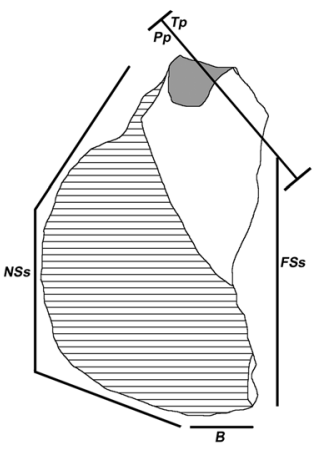

$\mathrm{m}$

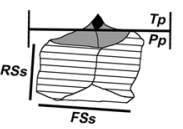

$\mathrm{b}$

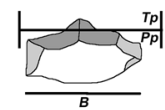

C

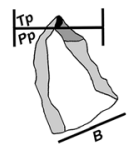

d

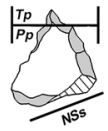

i
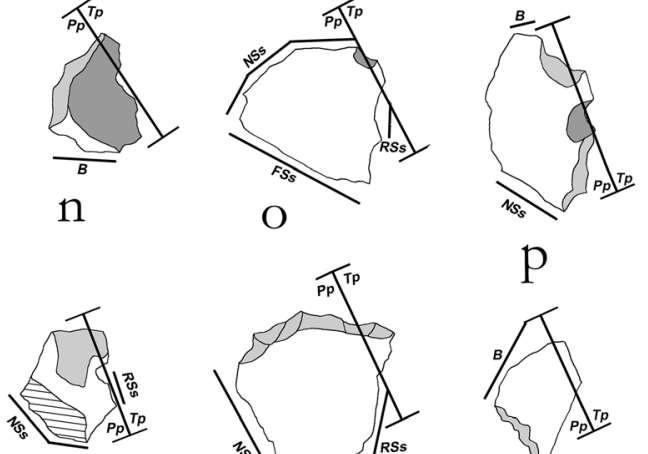

$\mathbf{r}$
$\mathrm{O}$

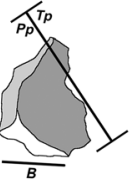

n

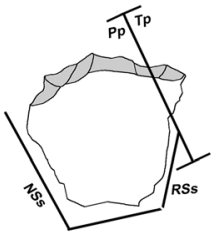

S

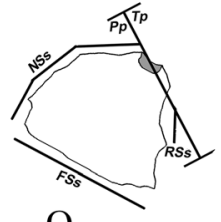

$\mathrm{P}$

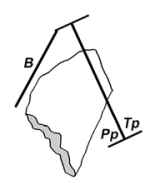

$t$

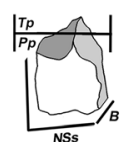

e
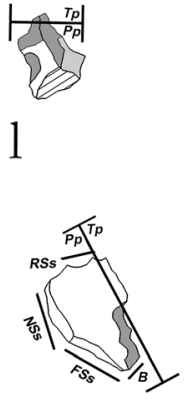

q

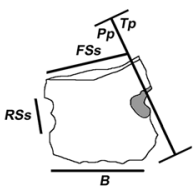

u

Fig. 8 The Fontana Ranuccio lithic industry. A schematic representation of the main techno-functional features of the pointed $(\mathrm{a}-\mathrm{l})$ and cutting $(\mathrm{m}-\mathrm{u})$ tools. Tools are oriented according the location of their transformative (Tp) and prehension ( $\mathrm{Pp}$ ) parts, regardless of their technical or morphological axe. Prehension part is shaped by means of steep retouch (light grey area or RSs black line when located on the opposite surface), retouched notches (dark grey area), natural (horizontal lines area or NSs black line when located on the opposite surface) or fractured (FSs) or butt (B) steep sides (Credits: S. Grimaldi, University of Trento) 


\section{Discussion}

Broadly speaking, retouch seems to be used as a real technical process in which façonnage and débitage (following the definitions in Inizian et al. 1999) are tightly interconnected and superimposed one on the other. What seems relevant here is the need to shape a specific design of the tools by retouching the original morphology of very different blanks (such as, raw pebbles, split pebbles, flakes, fragments). In other words, the first two reduction stages described above do not seem to be relevant in the production system adopted by the hominins at Fontana Ranuccio. During these stages, direct and anvil percussion techniques, raw material economy, management of raw material volume, and qualitative and quantitative production of blanks are not a result of choices in terms of technical production outputs. They appear to have little-if any-relevance when the final goal of the production is considered. They look like mere expedients, randomly applied in order to better match the raw material physical constraints (i.e. size and shape of the pebbles, quality of the chert, solutions to knapping accidents). A clear clue for these statements is provided by the choice to take advantage of non-retouched steep edges created by the natural morphology of blanks, such as steep cortical sides, or by deliberately fracturing the blanks. We are arguing here that the initialization and production stages allow us to suggest that hominin behaviour seems to follow an instinctive way of reasoning in terms of design planning during this part of the production process.

Once the production stage is completed and, consequently, a variety of blanks is available, what follows is the selection of those blanks that are suitable for retouch. It is quite hard to understand the cognitive criteria adopted by the Fontana Ranuccio hominins during the selection of the most appropriate blanks. A speculative assumption may consider the existence of an opportunistic attitude that plays as a conceptual guide. Whatever the criteria are, only after having concluded the selection process does a 'rational mind' become visible to us in terms of technological, morphological, and functional standardization. This is made evident by the way retouch (the refinement stage in our reduction sequence) is applied, and how it plays a fundamental role in the production process of the tools. The significance of retouch as a technical device is also stressed when it is compared with other technical expedients useful for creating steep sides to shape the prehension part of the tool, such as débordant or natural sides of the blanks and/or the thick and large butt surfaces and/or the fracturing of blanks. In other words, the adoption of these technical devices in order to produce blanks as well as to shape them into tools makes it very difficult to draw a clear line between the débitage and façonnage (as already noticed by Aureli et al. 2016, 178).

Retouch is also used to shape the transformative part of the tools: retouched notches (when pointed tools are concerned) and flat retouch (when cutting tools are concerned) are the main solutions in this regard. This leads us to another issue, namely, the adaptive role and, consequently, the evolutionary significance of flat retouch when compared with steep retouch. In fact, we would like to stress that, at least in Fontana Ranuccio, while flat retouch seems to be generally adopted to shape the transformative part of tools, steep retouch is generally adopted to shape the prehension part of tools. The former is clearly an indispensable and irreplaceable device to obtain a desired goal, while the latter can be applied in different ways and can also be replaced by other technical expedients. This issue deserves a more developed study. Nevertheless, we 
would still like to mention that flat retouch should be considered as one of the main technical achievements during the Lower Palaeolithic, as it is also useful to shape thinner and more symmetrical bifaces.

The terms we use above, such as 'rational mind' or 'instinctive way of reasoning', should be considered as a rough, speculative attempt to investigate archaic, non- $H$. sapiens' cognitive functions. It is quite clear that this is a very difficult task, and here it is also strictly related to the study of the Fontana Ranuccio assemblage. Unfortunately, very few case studies are known in the literature that can be compared with the Fontana Ranuccio one. Several Lower Palaeolithic sites are found in Italy, such as Torre in Pietra (Villa et al. 2016), Isernia (Gallotti and Peretto 2014), Polledrara (Santucci et al. 2016), and Notarchirico (Santagata 2016). Despite attempts to technologically analyse the lithic assemblages found in these sites, the only fully reconstructed reduction sequence currently known in the literature is the one from the site of Ficoncella, an open air site in Central Italy, dated to about 0.5 Ma (MIS 13). Here, authors suggest the existence of a 'circular reduction sequence' (Aureli et al. 2016, fig. 11) applied to small pebbles where 'the first produced flake can be a blank for a first tool, while part of the block that remains can be also shaped for the construction of a second tool. The confection flakes, coming from the tool shaping, can be used themselves... and so on' (Aureli et al. 2016, 181). There are many techno-functional similarities between the Fontana Ranuccio and Ficoncella lithic assemblages: (a) retouch plays a fundamental role to shape the desired tools; (b) small tools play the role of desired tools; (c) the superimposition and mixture of façonnage and débitage in order to produce blanks as well as tools; (d) the use of technical expedients - such as the fracturing of blanks - to obtain suitable blanks or to shape them at the place of retouch; (e) finally, the main typological morphologies produced at Ficoncella - i.e. spina, rostrum, and cutting edges - are very similar to the pointed and cutting tools found in Fontana Ranuccio.

Techno-functional similarities to those found at Fontana Ranuccio and Ficoncella may be found in another Lower Palaeolithic open air site in Central Italy: Valle Giumentina. Here, a fully reconstructed reduction sequence is still lacking but the study of the techno-functional features of the Valle Giumentina industry (Nicoud et al. 2015, fig. 4) allows us to detect a very similar behaviour among these sites. In fact, the authors describe the presence of several types of cutting tools, trihedral points - sometimes created thanks to voluntary fracturesdenticulate cutting-edges, and notches 'sometimes created by several rows of removals which reinforce the flat-concave section' (Nicoud et al. 2015, 8). Quite interestingly, the authors refer to this lithic assemblage as 'a single concept of core volumetric structure. It can be described as ' $\mathrm{C}$ type', belonging to an 'abstract' production concept, following Boëda 2013' (Nicoud et al. 2015, 9). Nevertheless, in the same study, the authors assess that the Valle Giumentina lithic assemblage 'is essentially made of the last step of the production chaîne opératoire' (Nicoud et al. 2015, 10) so to show 'the fragmentation in time and space of the production chaine opératoire and demonstrate the territorial mobility of the human groups' (Nicoud et al. 2015, 12). In this regard, we argue that the strong similarities as well as the relevant behavioural complexity shown by these lithic assemblages seem to suggest more caution is needed when mobility patterns are discussed.

In conclusion, beyond attempts to interpret Lower Palaeolithic lithic assemblages, we aim to stress the remarkable value of a true techno-functional approach. We are convinced that future, more developed analyses in this field will bring forth more and more information to better understand the hominin behaviour. 
Acknowledgements Open access funding provided by Università degli Studi di Trento within the CRUICARE Agreement. Authors are grateful to the staff of the Convitto Nazionale 'Regina Margherita' for helping us during our staying in Anagni and to David J. Cohen for having revised the English text and for his comments. We warmly thank the two anonymous reviewers for their help in improving our manuscript and the editor in chief for his comments.

Funding Excavations at Fontana Ranuccio and research activity were supported by BancAnagni under grant 'Istituto Italiano di Paleontologia Umana' and Department of Humanities of University of Trento (Trento, Italy) under grant 'Ricerca Base - Grimaldi'. This work is part of the activities by the CeASUm (Center for High Humanity Studies, University of Trento) for the Project Dipartimento di Eccellenza financed by the Italian Ministry for the University and Research. The excavation at Fontana Ranuccio is authorized by the Ministero dei beni e delle attività culturali e del turismo, the Soprintendenza Archeologia Belle Arti e Paesaggio per le Province di Frosinone, Latina e Rieti; the Regione Lazio supports the research activity of the Italian Institute of Human Paleontology.

\section{Compliance with Ethical Standards}

Conflict of Interest The authors declare that they have no conflict of interest.

Open Access This article is licensed under a Creative Commons Attribution 4.0 International License, which permits use, sharing, adaptation, distribution and reproduction in any medium or format, as long as you give appropriate credit to the original author(s) and the source, provide a link to the Creative Commons licence, and indicate if changes were made. The images or other third party material in this article are included in the article's Creative Commons licence, unless indicated otherwise in a credit line to the material. If material is not included in the article's Creative Commons licence and your intended use is not permitted by statutory regulation or exceeds the permitted use, you will need to obtain permission directly from the copyright holder. To view a copy of this licence, visit http://creativecommons.org/licenses/by/4.0/.

\section{References}

Agam, A., \& Barkai, R. (2015). Not the brain alone: the nutritional potential of elephant heads in Paleolithic sites. Quaternary International, 406, 1-89.

Agam, A., \& Barkai, R. (2018). Elephant and mammoth hunting during the Paleolithic: a review of the relevant archaeological, ethnographic and ethno-historical records. Quaternary. https://doi.org/10.3390 /quat1010003.

Agam, A., Marder, O., \& Barkai, R. (2015). Small flake production and lithic recycling at late Acheulian Revadim, Israel. Quaternary International, 361, 46-60.

Alperson-Afil, N., \& Goren-Inbar, N. (2016). Acheulian hafting: proximal modification of small flint flakes at Gesher Benot Ya'aqov, Israel. Quaternary International, 411, $34-43$.

Andrefsky, W. (2005). Lithics: macroscopic approaches to analysis. Cambridge: Cambridge University Press.

Angelucci, D.E. (2002). The geoarcheological context. In J. Zilhão, E. Trinkaus (Eds.), Portrait of the artist as a child. The Gravettian human skeleton from the Abrigo do Lagar Velho. Trabalhos de Arqueologia, 22, 58-91.

Aranguren, B., Grimaldi, S., Benvenuti, M., Capalbo, C., Cavanna, F., Cavulli, F., Ciani, F., Comencini, G., Giuliani, C., Grandinetti, G., Mariotti Lippi, M., Masini, F., Mazza, P., Pallecchi, P., Santaniello, F., Savorelli, A., \& Revedin, A. (2019). Poggetti Vecchi (Tuscany, Italy): a late Middle Pleistocene case of human elephant interaction. Journal of Human Evolution, 133, 32-60.

Ascenzi, A., Biddittu, I., Cassoli, P. F., Segre, A. G., \& Segre Naldini, E. (1993). Dal Paleolitico inferiore al Bronzo nel bacino di Anagni. In S. Gatti (Ed.), Dives Anagnia dalla preistoria alla protostoria. Archeologia della Valle dei Sacco (pp. 25-47). L'Erma di Bretschneider: Roma.

Aureli, D., Rocca, R., Lemorini, C., Modesti, V., Scaramucci, S., Milli, S., Giaccio, B., Marano, F., Palombo, M. R., \& Contardi, A. (2016). Mode 1 or mode 2? "Small tools" in the technical variability of the European Lower Palaeolithic: the site of Ficoncella (Tarquinia, Lazio, Central Italy). Quaternary International, 393, 169-184. 
Biddittu, I., \& Bruni, L. (1987). Il rinvenimento di una amigdala in osso del Paleolitico inferiore a Fontana Ranuccio. Latium, 4, 3-6.

Biddittu, I., \& Segre, A. G. (1984). Industria su scheggia e bifacciali: nuovi reperti del paleolitico inferiore ad Anagni-Fontana Ranuccio, Frosinone. Atti della XXIV riunione scientifica dell'Istituto Italiano di Preistoria e Protostoria, 24, 105-112.

Bietti, A., \& Grimaldi, S. (1991). Patterns of reduction sequences at Grotta Breuil: statistical analyses and comparisons of archaeological vs. experimental data. Quaternaria Nova, I, 379-406.

Bietti, A., Cancellieri, E., Corinaldesi, C., Grimaldi, S. \& Spinapolice E. (2009-2010). La percussion sur enclume en Italie centrale Tyrrhénienne. Paléo, numero special, 143-180.

Boeda, E. (1994). Le concept Levallois: variabilité des méthodes. Paris: CNRS.

Boëda, E. (1997). Technogenése de systémes de production lithique au Paléolithique inférieur et moyen en Europe occidentale et au Proche-Orient. Habilitation à diriger des recherches. Nanterre: Universitée de Paris X.

Boëda, E. (2001). Détermination des unités techno-fonctionnelles de piéces bifaciales provenant de la couche acheuléenne C'3 base du site de Barbas I. In D. Cliquet (Ed.), Les industries à outils bifaciaux du Paléolithique moyen d'Europe occidentale (pp. 51-75). Caen: Actes de la Table Ronde internationale 1999. Liége: Eraul 98.

Boëda, E. (2005). Paléo-technologie ou anthropologie des techniques? Arob@se, 1, 46-64.

Boëda, E. (2013). Techno-logique et technologie. In Une paleo-histoire des objets lithiques tranchants. Paris, @ rchéo-éditions.

Bonilauri, S. (2010). Les outils du Paléolithique moyen: une mémoire technique oubliée? Approche technofonctionnelle appliquée à un assemblage lithique de conception Levallois provenant du site d'Umm el Tlel (Syrie centrale) (Ph.D. thesis). Université Paris Ouest Nanterre, France.

Bordes, F. (1961). Typologie du Paléolithique ancien et moyen. Delmas: Bordeaux.

Bourguignon, L. (1997). Le Moustérien de type Quina: nouvelle définition d'une entité technique (Ph.D. thesis). Université Paris X Nanterre, France.

Burdukiewicz, J. M. \& Ronen, A. (Eds.) (2003). Lower Palaeolithic small tools in Europe and the Levant. BAR (I.S.), 239.

Carbonell, E., Mosquera, M., Rodríguez, X. P., Sala, R., \& Made, J. V. D. (1999). Out of Africa: the dispersal of the earliest technical systems reconsidered. Journal of Anthropological Archaeology, 18, 119-136.

Cassoli, P. F., \& Segre Naldini, E. (1984). Nuovo contributo alla conoscenza delle faune villafranchiane e del Pleistocene medio del bacino di Anagni (Frosinone). Atti della XXIV riunione scientifica dell'Istituto Italiano di Preistoria e Protostoria, 24, 115-118.

Chevrier, B. (2012). Les assemblages à piéces bifaciales au Pléistocéne inférieur et moyen ancien en Afrique de l'Est et au Proche-Orient. Nouvelle approche du phénoméne bifacial appliquée aux problématiques de migrations, de diffusion et d'évolution locale (Ph.D. thesis). Université Paris Ouest Nanterre, France.

Clark, G. (1969). World prehistory. A new outline (2nd ed.). London: Cambridge University Press.

Crovetto, C., Ferrari, M., Peretto, C., \& Vianello, F. (1994). La sperimentazione litica. In C. Peretto (Ed.), Le industrie litiche del giacimento paleolitico di Isernia (pp. 119-182). Isernia La Pineta: Cosmo Iannone Editore.

Gallotti, R., \& Peretto, C. (2014). The Lower/early Middle Pleistocene small débitage productions in Western Europe: new data from Isernia La Pineta t.3c (Upper Volturno Basin, Italy). Quaternary International. https://doi.org/10.1016/j.quaint.2014.06.055.

Grimaldi, S. (1996). Mousterian reduction sequences in Central Italy. Quaternaria Nova, VI, 279-310.

Grimaldi, S., \& Santaniello, F. (2014). New insights into Final Mousterian lithic production in western Italy. Quaternary International, 350, 116-129.

Grimaldi, S., Rosina, P., \& Boton, F. (1999). A behavioral perspective on "archaic" lithic morphologies in Portugal. The case of Fonte da Moita open air site. Journal of Iberian Archeology, 1, 33-57.

Inizian, M.L., Reduron-Ballinger, M., Roche, H., \& Tixier, J. (1999). Technology and terminology of knapped stone. Préhistoire de la pierre taillée tome 5, CREP.

Lemorini, C. (2018). Small tools and the Palaeoloxodon. Homo interaction in the Lower Palaeolithic: the contribution of use-wear analysis. In V. Borgia \& E. Cristiani (Eds.), Palaeolithic Italy. Advanced studies on early human adaptations in the Apennine peninsula (pp. 27-36). Leiden: Sidestone Press.

Lepot, M. (1993). Approche techno fonctionnelle de l'outillage lithique mousterien: essai de classification des parties actives en terme d'efficacité technique (Master thesis). Université Paris X Nanterre, France.

Manzi, G., Magri, D., \& Palombo, M. R. (2011). Early-Middle Pleistocene environmental changes and human evolution in the Italian peninsula. Quaternary Science Reviews, 30, 1420-1438.

Marinelli, F., Lemorini, C., \& Zampetti, D. (2019). La funzione degli “small tools" nell'ambito delle industrie litiche scheggiate acheuleane della penisola italiana: il caso studio del sito laziale di Fontana Ranuccio (FR). IpoTesi di Preistoria, 11, 57-72. 
Marra, F., Karner, D. B., Freda, C., Gaeta, M., \& Renne, P. (2009). Large mafic eruptions at Alban Hills Volcanic District (Central Italy): chronostratigraphy, petrography and eruptive behavior. Journal of Volcanology and Geothermal Research, 179, 217-232.

Marreiros, J. M., Gibaja Bao, J. F., \& Bicho, N. F. (Eds.). (2015). Use-wear and residue analysis in archaeology. Berlin: Springer.

Mourre, V. \& Jarry, M. (Eds.) 2009-2010. Entre le marteau et l'enclume...La percusion directe au percuteur dur et la diversité de ses modalités d'application. Paleo, n.s.

Muttoni, G., Scardia, G., Kent, D. V., Swisher, C. C., \& Manzi, G. (2009). Pleistocene magnetochronology of early hominin sites at Ceprano and Fontana Ranuccio, Italy. Earth and Planetary Science Letters, 286, 255-268.

Nicoud, E. (2011). Le phénoméne acheuléen en Europe occidentale: approche chronologique, technologie lithique et implications culturelles (Ph.D. thesis). Université de Provence Aix-Marseille III, France and Università di Roma La Sapienza, Italy.

Nicoud, E. (2013). What does the Acheulean consist of? The example of Western Europe (MIS 16-9). Mitteilungen der Gesellschaft für Urgeschichte, 22, 41-60.

Nicoud, E., Aureli, D., Pagli, M., Villa, V., Chaussé, C., Agostini, S., Bahain, J. J., Boschian, G., Degeai, J.-P., Fusco, F., Giaccio, B., Hernandez, M., Kuzucuoglu, C., Lahaye, C., Lemorini, C., Limondin-Lozouet, N., Mazza, P., Mercier, N., Nomade, S., Pereira, A., Robert, V., Rossi, M. A., Virmoux, C., \& Zupancich, A. (2015). Preliminary data from Valle Giumentina Pleistocene site (Abruzzo, Central Italy): a new approach to a Clactonian and Acheulian sequence. Quaternary International, 409, 182-194.

Pereira, A., Nomade, S., Moncel, M.-H., Voinchet, P., Bahain, J.-J., Bidittu, I., Falguéres, C., Giaccio, B., Manzi, G., Parenti, F., Scardia, G., Scao, V., Sottili, G., \& Vietti, A. (2018). Integrated geochronology of Acheulian sites from the southern Latium (Central Italy): Insights on human-environment interaction and the technological innovations during the MIS11-MIS10 period. Quaternary Science Reviews, 187, 112-129.

Rocca, R. (2013). Peut-on définir des aires culturelles au Paléolithique inférieur ?: originalité des premières industries lithiques en Europe centrale dans le cadre du peuplement de l'Europe. Thèse de doctorat en Préhistoire, École doctorale Milieux, cultures et sociétés du passé et du présent (Nanterre).

Rocca, R. (2015). First settlements in Central Europe: between originality and banality. Quaternary International. https://doi.org/10.1016/j.quaint.2015.08.066.

Rocca, R., Abruzzese, C., \& Aureli, D. (2016). European Acheuleans: critical perspective from the east. Quaternary International, 411, 402-411.

Rubini, M., Cerroni, V., Festa, G., Sardella, R., \& Zaio, P. (2014). A revision of hominin fossil teeth from Fontana Ranuccio (Middle Pleistocene, Anagni, Frosinone, Italy). Journal of Human Evolution, 77, 204-216.

Santagata, C. (2016). Operating systems in units B and E of the Notarchirico (Basilicata, Italy) ancient Acheulean open-air site and the role of raw materials. Quaternary International, 411, 284-300.

Santucci, E., Marano, F., Cerilli, E., Fiore, I., Lemorini, C., Palombo, M. R., Anzidei, A. P., \& Bulgarelli, G. M. (2016). Palaeoloxodon exploitation at the Middle Pleistocene site of La Polledrara di Cecanibbio (Rome, Italy). Quaternary International, 406, 169-182.

Segre, A. G., \& Ascenzi, A. (1984). Fontana Ranuccio: Italy's earliest Middle Pleistocene hominid site. Current Anthropology, 25(2), 230-233.

Segre Naldini, E., Muttoni, G., Parenti, F., Scardia, G., \& Segre, A. G. (2009). Nouvelles recherches dans le bassin Plio-Pléistocene d'Anagni (Latium méridional, Italie). L'anthropologie, 113, 66-77.

Song, Y., Grimaldi, S., Santaniello, F., Cohen, D. J., Shi, J., \& Bar-Yosef, O. (2019). Re-thinking the evolution of microblade technology in East Asia: Techno-functional understanding of the lithic assemblage from Shizitan 29 (Shanxi, China). PLoS One, 14(2). https://doi.org/10.1371/journal.pone.0212643.

Strani, F., DeMiguel, D., Bona, F., Sardella, R., Biddittu, I., Bruni, L., DeCastro, A., Guadagnoli, F., \& Bellucci, L. (2018). Ungulate dietary adaptations and palaeoecology of the Middle Pleistocene site of Fontana Ranuccio (Anagni, Central Italy). Palaeogeography, Palaeoclimatology, Palaeoecology, 496, 238-247.

Villa, P., Soriano, S., Grün, R., Marra, F., Nomade, S., Pereira, A., Boschian, G., Pollarolo, L., Fang, F., \& Bahain, J. J. (2016). The Acheulian and Early Middle Paleolithic in Latium (Italy): stability and innovation. PLoS One, 11(8), e0160516. https://doi.org/10.1371/journal.pone.0160516.

Zanolli, C., Martinon-Torres, M., Bernardini, F., Boschian, G., Coppa, A., Dreossi, D., Mancini, L., Martinez de Pinillos, M., Martin-Francés, L., Bermudez de Castro, J. M., Tozzi, C., Tuniz, C., \& Macchiarelli, R. (2018). The Middle Pleistocene (MIS 12) human dental remains from Fontana Ranuccio (Latium) and Visogliano (Friuli-Venezia Giulia), Italy. A comparative high resolution endostructural assessment. PLoS One, 13(10). https://doi.org/10.1371/journal.pone.0189773.

Publisher's Note Springer Nature remains neutral with regard to jurisdictional claims in published maps and institutional affiliations. 